\title{
WORK ETHICS AND EMPLOYEE PASSION IN GOVERNMENT PARASTATAL IN RIVERS STATE
}

\section{PEACE UDEKA IBIYEOMIE}

Scholar, Department of Management, Ignatius Ajuru, University of Education, Port Harcourt, River State. Nigeria

\begin{abstract}
The study examined the relationship between work ethics and employee passion of government parastatal in Rivers State. A survey study is carried out on 10 randomly selected government parastatal in Rivers State. 2200 employees of the selected firms constitute the population and the sample size is 327. The instrument for the study is a questionnaire rated on 4point Likert scale of strongly agreed, agreed disagreed and strongly disagree. 327 questionnaires were administered, the analyses were based on the 295 questionnaires returned. Spearman rank Correlation Coefficient was used for the analysis. The findings reveal a significant correlation between work ethics and employee passion. All the dimensions of work ethics relate with employee passion. The study concludes that work ethics has relationship with employee work passion and recommended inculcation of discipline, time management and integrity in worker and encouraging a passionate worker.
\end{abstract}

KEYWORDS: Work Ethics, Discipline, Time management, Integrity, Harmonious passion, Obsessive passion

Received: Dec 19, 2020; Accepted: Jan 09 2021; Published: Feb 18, 2021; Paper Id.: IJAFMRJUN20211

\section{INTRODUCTION}

Every organisation desires to have employees with positive traits that boost performance. The loyalty to ethical standards determines the well-being of the entire organisation and the stakeholders. Strong ethics are developed over time, the educational path undertaken continuously by individual develop their trait and work ethics. The work ethics, resourcefulness, and energy of employees are related to their passion for work. Employees’ passion for work dictates the traits they exhibit at work, their productivity and performance.

Passion for work is an important element for sustained long- term performance. But often, it becomes difficult to assess and know if passion for work exists at the staffing stage, as all candidate exhibits traits of having passion for the work they applied for. For a country where investment and development are low, poverty travails, and joblessness becomes a normal issue, people accept job opportunities just to have a means of livelihood and because of this, unethical behaviour is exhibited.

In most of the jobs, the compensation attached to job roles are very poor, this made it difficult to satisfy their needs and desires and subsequently arouse unethical behaviours which affects self-discipline, etiquette, integrity and productivity. The government parastatal has become a dumping place for those who cannot secure their desired work. When they coexist at work, with time, they display unethical behaviour that shows no passion for their job roles. This awful failure to maintain ethical behaviour at workplace causes incessant questioning of these multifaceted issues that arise from passion and unethical behaviour. This motivates the researcher to examine the relationship between work ethics and employee work passion. 


\section{RESEARCH QUESTION}

What is the relationship between:

- Discipline and employee passion in government parastatal in Rivers State?

- Time management and Employee Passion in government parastatal in Rivers State?

- Integrity and Employee Passion in government parastatal in Rivers State?

\section{RESEARCH HYPOTHESES}

- Ho $\mathrm{Ho}_{1}$ Discipline does not significantly relate with obsessive passion in government parastatal in Rivers State.

- $\mathrm{Ho}_{2}$ : Discipline does not significantly relate with harmonious passion in government parastatal in Rivers State.

- $\mathrm{Ho}_{3}$ : Time management does not significantly relate with obsessive passion in government parastatal in Rivers State.

- Ho H $_{4}$ Time management does not significantly relate with harmonious passion in government parastatal in Rivers State.

- Ho5: Integrity does not significantly relate with obsessive passion in government parastatal in Rivers State.

- Ho Ho $_{6}$ Integrity does not significantly relate with harmonious passion in government parastatal in Rivers `State.

\section{REVIEW OF RELATED LITERATURE}

Ethics are moral values that govern an individual's behaviour (Oxford Dictionary, 2020) to decide. Work ethics are ethical standards that guide individuals towards effective implementation of their work in a formal environment (Cote, 2019). Ethics has different meaning to people, to some it is a drive that motivates them at work, it also refers to attitudes and behaviour at workplace, while some see it as sets of skill required for executing a job and responsibilities of a role.

Work ethics are a code of conduct governing workers behaviour (Velaesquaez, 2002). Work ethics is instilling physical, intellectual and emotive effort into one's job to meet or surpass potentials through commitment to one's job and employer. Some work ethics exhibited at workplace is discipline. Timeliness and integrity, and these are the measures of work ethics in this study.

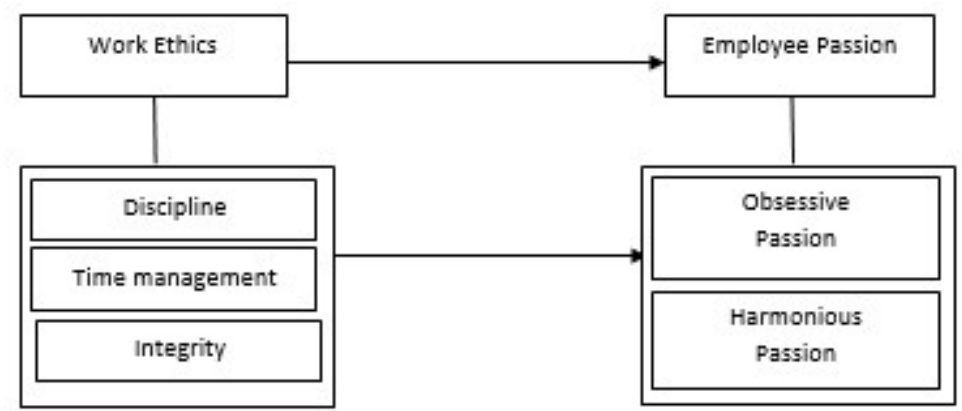

Figure 1: Conceptual framework of work ethics and employee passion.

Source: Researcher, 2021.

Work place efficiency and growth require discipline. Discipline is an attribute that emanates from within. An employee with no passion for discipline will consistently exhibits disorderliness which may result in negative thoughts, attitudes and behaviour, Self-discipline is a positive self-reliance, focus, control, sufficiency and determination by an 
individual to do the right things at the workplace. Workplace discipline are activities directed towards guiding thoughts, actions, habits, attitudes and behaviours of workers towards a targeted goals achievement. It is an act of dedication, enthusiasm and devotion amid the workers for positive results and productivity

Disregard for time management is obviously becoming a normal thing in government establishment in Nigeria. Only few individuals and institutions have a passion for timeliness and this occurrence cut across all employees, and thus, the cliché "African Time". Timelines does not show a sense of values in any organisation, it results in wasted time, unwanted stress, poor workflow and quality of task, poor professionalism, strained workplace relationship, work and life imbalance and it give bad reputation to individuals and the institution involved, but having good time management make up an excellent work ethics, as it results in greater productivity accomplishment and commitment to the ultimate goal. Time management is planning and exercising conscious control of the time spent on specific activities (Kashyap, 2021).

A focused employee, who does the right thing at the right time can achieve a lot more and complete more goals as inability to use time appropriately result in time mismanagement, and therefore getting to work early shows a magnificent work ethic from workers.

Time management is essential in all institutions as it gives more opportunities, wise prioritisation of activities, enhances setting time limit for targets, enhance setting right goals, reduces work stress, removing non-essential tasks, give opportunity for breaks within activities, enhance planning and the ability to have self-organisation (Corporate Finance Institute, 2020). Time is limited, therefore, it essential to have an awareness of scarcity of time, effectively use time and monitor time usage, manipulate and organise schedules, plans, tasks, and goals in all activities.

A critical and important value/ work ethic required at workplace is integrity. Integrity exercises honesty, truthfulness, consistency and obdurate adherence to strong moral and ethical values and ethics (Wikipedia, 2020). Integrity in individuals are actions that are moral and based on internally consistent principles. Kang (2017) posits that integrity requires an inner sense of 'wholeness' and consistency of character that are visibly seen in actions, decisions, words, methods and outcomes.

It is a foundation for building trust, relationships and the values desired by employers in their employees. These values are honesty, accountability, responsibility, self-awareness, and internally consistent actions. An intelligible person will not compromise for fraud, bribery and corruption as it is against their internally consistent principles.

Employee passion is the desire or craving that drives individual aspirations. Passion for work is a strong enthusiasm for one's job role (Akuma, 2018). It is vital to employee creativity, innovations and individual work ethics, organisational goals and growth achievement. Passion provides the drive and inspiration needed to excel and be fulfilled at work, and not being passionate about the work might not make success to be meaningful or fulfilling and subsequently result in decrease moral values. According to Tanveer Naseer Leadership (2012) organisations have realised that they cannot depend on the analytical side of their employees, but need to integrate a whole-person approach, to be viable and effective in today's evolving global market.

The employee passion for work defines the individual excitement, creativity, paths, attitude, self-development, discipline, integrity, timeliness, productivity and behaviour towards obstacles solving. According to Hagel, Brown, Ranjan 'India, \& Byler (2013), a passionate worker is defined by their commitment, questing, and connecting and these attributes drive sustained performance improvement and knowledge integration that produces longer impact disciplined commitment. 
The measures of passion in this study are harmonious and obsessive passion. Harmonious passion occurs when an individual partakes in adored activities and is fulfilled through positive affective outcomes that create commitment, engagement, and happy environment. Harmonious passion internalised positive affective outcomes the work ethics considered important into an identity that produces motivation for willingly carrying out the task while obsessive passion occurs when an irresistible desire to take part in an endeavour triggers pressure that makes one lose control of self and relationship. You feel compelled to continue to take part in this activity and can't seem to pull yourself away from it. This type of passion has negative influences on wellbeing and creating stress that results in unethical practices.

The study is anchored on Self-Determination Theory (SDT) that posits that persons have a natural inclination to adopt some activities within themselves, and this is contingent on the importance and value of these activities on an individual's identity.

\section{METHODOLOGY}

A survey study is carried out on 10 randomly selected governments parastatal in Rivers State, the population of study comprises 2200 employees of the selected firms and the sample size is 327.the instrument for the study is a questionnaire rated on 4point Likert scale of strongly agreed, agreed disagreed and strongly disagree. 327 questionnaires were administered, the analyses were based on the 295 questionnaires returned. Spearman rank Correlation Coefficient was used for the analysis.

\section{RESULTS AND FINDINGS}

Table 1: Correlation of Discipline and Employee Passion

\begin{tabular}{|c|c|c|c|c|c|}
\hline & & & Discipline & $\begin{array}{l}\text { Obsessive } \\
\text { Passion }\end{array}$ & Harmonious passion \\
\hline & Discipline & $\begin{array}{l}\text { Correlation } \\
\text { Coefficient }\end{array}$ & 1.000 & $.375^{* *}$ & $.495^{* *}$ \\
\hline & & Sig. (2-tailed) & & .000 & .000 \\
\hline & & $\mathrm{N}$ & 295 & 295 & 295 \\
\hline & $\begin{array}{l}\text { Obsessive } \\
\text { Passion }\end{array}$ & $\begin{array}{l}\text { Correlation } \\
\text { Coefficient }\end{array}$ & $.375^{* *}$ & 1.000 & $.435^{* *}$ \\
\hline & & Sig. (2-tailed) & .000 & & .000 \\
\hline & & $\mathrm{N}$ & 295 & 295 & 295 \\
\hline & $\begin{array}{l}\text { Harmonious } \\
\text { passion }\end{array}$ & $\begin{array}{l}\text { Correlation } \\
\text { Coefficient }\end{array}$ & $.495^{* *}$ & $.435^{* *}$ & 1.000 \\
\hline$\stackrel{\infty}{\equiv}$ & & Sig. (2-tailed) & .000 & .000 & \\
\hline $\begin{array}{l}\bar{E} \\
\stackrel{0}{0} \\
\frac{0}{n}\end{array}$ & & $\mathrm{~N}$ & 295 & 295 & 295 \\
\hline
\end{tabular}




\section{Source: SPSS Output, 2021.}

Table 1 display the relationship Between Discipline and Employee Passion.

Discipline and Obsessive passion: The result shows a significant level $p<0.05(0.000<0.05)$, rho $=0.375^{* *}$. It shows a significant positive relationship between discipline and obsessive passion. Although, the correlational value is low. The null hypothesis, $\mathrm{Ho}_{1}$, is rejected, and the alternate accepted.

Discipline and Harmonious passion: The result of the data in table 1 shows a significant level $\mathrm{p}<0.05(0.000<0.05)$, rho $=0.495^{* *}$. The results reveal a moderately significant relationship between discipline and harmonious passion. We therefore reject the null hypothesis, $\mathrm{Ho}_{2}$, and accept the alternate.

The result shows that discipline is a work ethics that is influenced by an individual passion for work.

Table 2: Correlation of Time Management and Employee Passion

\begin{tabular}{|c|c|c|c|c|c|}
\hline & & & $\begin{array}{c}\text { Time } \\
\text { Management }\end{array}$ & $\begin{array}{c}\text { Obsessive } \\
\text { Passion }\end{array}$ & Harmonious passion \\
\hline \multirow{9}{*}{ 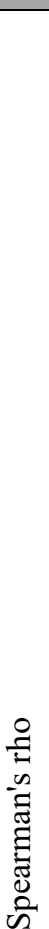 } & \multirow[t]{3}{*}{$\begin{array}{l}\text { Time } \\
\text { Management }\end{array}$} & $\begin{array}{l}\text { Correlation } \\
\text { Coefficient }\end{array}$ & 1.000 & $.425^{* *}$ & $.535^{* *}$ \\
\hline & & Sig. (2-tailed) & & .000 & .000 \\
\hline & & $\mathrm{N}$ & 295 & 295 & 295 \\
\hline & \multirow[t]{3}{*}{$\begin{array}{l}\text { Obsessive } \\
\text { Passion }\end{array}$} & $\begin{array}{l}\text { Correlation } \\
\text { Coefficient }\end{array}$ & $.425^{* *}$ & 1.000 & $.478^{* *}$ \\
\hline & & Sig. (2-tailed) & .000 & & .000 \\
\hline & & $\mathrm{N}$ & 295 & 295 & 295 \\
\hline & \multirow[t]{3}{*}{$\begin{array}{l}\text { Harmonious } \\
\text { passion }\end{array}$} & $\begin{array}{l}\text { Correlation } \\
\text { Coefficient }\end{array}$ & $.535^{* *}$ & $.478^{* *}$ & 1.000 \\
\hline & & Sig. (2-tailed) & .000 & .000 & \\
\hline & & $\bar{N}$ & 295 & 295 & 295 \\
\hline
\end{tabular}

Source: SPSS Output, 2021.

Table 2 shows the relationship between Time Management and Employee Passion.

Time Management and Obsessive passion: The result shows a significant level $\mathrm{p}<0.05(0.000<0.05)$, rho $=0.425^{* *}$. This implies a moderately positive relationship between time management and obsessive passion. The null hypothesis, $\mathrm{Ho}_{2}$, is rejected, and the alternate accepted.

Time Management and Harmonious passion: The result of the data in table 2 shows a significant level $\mathrm{p}<0.05(0.000<$ $0.05)$, rho $=0.535^{* *}$. The results reveal a moderate relationship between time Management and harmonious passion. We therefore reject the null hypothesis, $\mathrm{Ho}_{4}$, and accept the alternate. 
The result shows that time management is influenced by an individual passion for work.

Table 3: Correlation of Time Management and Employee Passion

\begin{tabular}{|c|c|c|c|c|c|}
\hline & & & Integrity & $\begin{array}{l}\text { Obsessive } \\
\text { Passion }\end{array}$ & Harmonious passion \\
\hline & Integrity & $\begin{array}{l}\text { Correlation } \\
\text { Coefficient }\end{array}$ & 1.000 & $415^{* *}$ & $.565^{* *}$ \\
\hline & & Sig. (2-tailed) & & .000 & .000 \\
\hline & & $\bar{N}$ & 295 & 295 & 295 \\
\hline & $\begin{array}{l}\text { Obsessive } \\
\text { Passion }\end{array}$ & $\begin{array}{l}\text { Correlation } \\
\text { Coefficient }\end{array}$ & $.415^{* *}$ & 1.000 & $.465^{* *}$ \\
\hline & & Sig. (2-tailed) & .000 & & .000 \\
\hline & & $\mathrm{N}$ & 295 & 295 & 295 \\
\hline 0 & $\begin{array}{l}\text { Harmonious } \\
\text { passion }\end{array}$ & $\begin{array}{l}\text { Correlation } \\
\text { Coefficient }\end{array}$ & $.565^{* *}$ & $465^{* *}$ & 1.000 \\
\hline 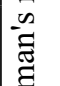 & & Sig. (2-tailed) & .000 & .000 & \\
\hline 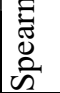 & & $\mathrm{N}$ & 295 & 295 & 295 \\
\hline
\end{tabular}

\section{Source: SPSS Output, 2021.}

Table 3 shows the relationship between Integrity and Employee Passion.

Integrity and Obsessive passion: The result shows a significant level $\mathrm{p}<0.05(0.000<0.05)$, rho $=0.415^{* *}$. This implies a moderate positive relationship between integrity and obsessive passion. The null hypothesis, Ho5, is rejected, and the alternate accepted.

Integrity and Harmonious passion: The result of the data in table 3 shows a significant level $p<0.05(0.000<0.05)$, rho $=0.565^{* *}$. The results reveal a moderate relationship between integrity and harmonious passion. We therefore reject the null hypothesis, $\mathrm{Ho}_{6}$, and accept the alternate.

The result shows that integrity in the organisation is a strong work ethics that is influenced by an individual passion for work.

\section{CONCLUSIONS}

Work ethic is the vital feature or trait that shows employee's reactions at work to a particular situation. The individual response and passion for work influences the possessed work ethics. An employee with a strong work ethics is a productive employee. The discipline, integrity and time management determine the sustainability and steadiness of the entity and individual passion influences workers decisions, morals, ethical practices and task performance. 


\section{RECOMMENDATIONS}

- Integrity should permeate every aspect of the employee task.

- The organisation should produce a disciplined workforce that will adhere to rules and follow through with their performance.

- The employees should inculcate time management culture for excellent performance.

- Employee should be passionate about their work.

\section{REFERENCES}

1. Akuma. P. (2018). Passion for work: 12 ways it helps your career. Jobberman.Com,

2. https://www.jobberman.com/blog/passion-for-work/. Assessed on 5/1/2021.

3. N. K. Gupta \& Jyoti Kasana , “An Empirical Study on the Effect of Business Ethics on the Company's CSR Practices “, International Journal of Business Management \& Research (IJBMR), Vol. 7, Issue 6, pp. 21-34

4. Corporate Finance Institute (2020). Time management. Corporate Finance Institute.Com,

5. https://corporatefinanceinstitute.com/resources/careers/soft-skills/time-management-list-tips/. Assessed on 5/1/2021.

6. Cote, A. (2019). The benefits of a strong work ethic, and how it can help you land and keep your dream job. Paymoapp.Com, https://www.paymoapp.com/blog/work-ethic/. Assessed on 3/1/2021.

7. Hagel. J., Brown, J.S., Ranjan India, A. \& Byler, D. Passion for work. Deloitte.Com,

8. behavior.html. Assessed on 1/5/2021.

9. Kang, S. (2017). The true meaning of integrity. Huffpost.Com, https://www.huffpost.com/entry/the-true-meaning-ofinteg_b_11273420?guccounter $=1 \&$ guce_referrer $=$ aHROcHM6Ly93d3cuZ29vZ2xlLmNvbS8\&guce_referrer_sig. Assessed on $5 / 1 / 2021$

10. Deepak Suryawanshi , "Technology, Development, Ethics and Culture “, International Journal of Applied Engineering Research and Development (IJAERD), Vol. 4, Issue 2, pp. 109-112

11. Kashyap, S. (2020). Importance of time management in the workplace. Proofhub.Com

12. https://www.proofhub.com/articles/importance-of-time-management-in-the-workplace. Assessed on 5/1/2021.

13. Oxford Dictionary (2020). Ethics. Google.Com,

14. https://www.google.com/search? $q=$ ethics\&oq=etics\&aqs=chrome.1.69i57j0i10i457j0i10i433j0i10l5.5076j1j15\&sourceid=ch rome\&ie $=U T F-8$. Assessed on 3/1/2021.

15. Chandrika K.B, "Need and Intervention of Social Workers in Public Health Care Services and Social Development ", International Journal of Humanities and Social Sciences (IJHSS), Vol. 4, Issue 1, pp. 57-62

16. Tanveer Naseer Leadership (2012). Bringing your passion back to work. Tanveernaseer.Com, https://www.tanveernaseer.com/why-passion-is-needed-in-the-workplace/. Assessed on 1/5/2021.

17. Simon Nderitu \& Munene George Mukigi, "Does Biblical Orthodoxy Result in Orthopraxy? A Case of Selected Public Secondary 89 Schools in Kiharu Division in Murang'a County, Kenya “, BEST: International Journal of Humanities, Arts, Medicine and Sciences (BEST: IJHAMS), Vol. 4, Issue 1, pp. 87-106

18. Velasquaez, M. G. (2002). Business, Ethics Concepts and Cases. New Delhi. Prentice-Hall. 5th edition. 
19. Wikipedia (2020). Integrity. En. Wikipedia.Org, https://en.wikipedia.org/wiki/Integrity. Assessed on 5/1/2021. 